Homo Psyche 



\title{
Homo Psyche
}

On Queer Theory and Erotophobia

\author{
GILA ASHTOR
}

Fordham University Press

NEW YORK 2021 


\section{Copyright (C) 2021 Fordham University Press}

All rights reserved. No part of this publication may be reproduced, stored in a retrieval system, or transmitted in any form or by any means-electronic, mechanical, photocopy, recording, or any other-except for brief quotations in printed reviews, without the prior permission of the publisher.

Fordham University Press has no responsibility for the persistence or accuracy of URLs for external or third-party Internet websites referred to in this publication and does not guarantee that any content on such websites is, or will remain, accurate or appropriate.

Fordham University Press also publishes its books in a variety of electronic formats. Some content that appears in print may not be available in electronic books.

Visit us online at www.fordhampress.com.

Library of Congress Cataloging-in-Publication Data

Names: Ashtor, Gila, author.

Title: Homo psyche : on queer theory and erotophobia / Gila Ashtor.

Description: New York : Fordham University Press, 2021. | Includes bibliographical references and index.

Identifiers: LCCN 2021014280 | ISBN 9780823294169 (hardback) | ISBN 9780823294152 (paperback) | ISBN 9780823294176 (epub)

Subjects: LCSH: Homosexuality-Psychological aspects. | Queer theory. | Erotophobia.

Classification: LCC HQ76.25 .A84 2021 | DDC 306.7601-dc23

LC record available at https://lccn.loc.gov/2021014280

Printed in the United States of America

$\begin{array}{llllllll}23 & 22 & 21 & 5 & 4 & 3 & 2 & 1\end{array}$

First edition 